Vol. 4: 27-33.

\title{
Biological quality of fermented fish offal and chicken by-products
}

T. Mikael Lassén

Division of Animal Nutrition, Department of Animal Science and Animal Health, Royal Veterinary and Agricultural University, Bülowsvej 13, DK-1870 Frederiksberg C., Denmark

\begin{abstract}
The biological quality of fermented animal by-products prepared from fish and chicken offal was evaluated. A quality index (QI) based on analyses of a few important free amino acids and their corresponding biogenic amines was given. A group separation method based on ion exchange chromatography was found suitable for isolating and purifying amines and amino acids in biological samples. Quality was evaluated in samples fermented with different starter cultures, inoculation sizes and substrate levels. Slow or incomplete fermentation led to the accumulation of biogenic amines, especially tyramine, and resulted in a low QI. Fast initial and continuous stable fermentation for four weeks resulted in low concentrations of biogenic amines and high concentrations of free amino acids and consequently a high QI. The alanine concentration was considered to be a useful tool for estimating proteolysis, and QI related to changes in alanine concentration, lactic acid production and redox potential were considered to give the most useful estimation of the biological quality of fermented fish offal and poultry waste.
\end{abstract}

Key words: biological silage, animal offal, biogenic amines, amino acids, HPLC

\section{Introduction}

Biogenic amines comprise a large and heterogeneous group of natural products of special interest owing to their physiological effects. They are produced in enzyme catalysed reactions with amino acids as direct precursors, some of which are common to all living cells. Amino acids are transformed into biogenic amines in sequences of reactions with several intermediates, some of which may be specific for biochemical reactions in many organisms, organs, tissues or cells (Eggum et al. 1988a). Amino acid decarboxylases (ADC) from microorganisms are important factors for production of biogenic amines (Børresen et al. 1988, Eggum et al. 1988a). Adverse effects on animal growth and health may be a result of excessively high dietary concentrations of both psychoactive and vasoactive biogenic amines (Eggum et al. 1988a).

The presence of biogenic amines in animal by-products such as fish and slaughter offal may have toxicological implications. Scombroid fish 


\section{AGRICULTURAL SCIENCE IN FINLAND}

\section{Lassén, T. M.: Biological quality of fermented fish offal and chicken by-products}

poisoning of humans occurs because of ingestion of pelagic fish, e.g. tuna and mackerel, which contain unusually high levels of histamine (Taylor 1986, 1988). Animal feeds often include whole fish, fish offal or fish meal, and large amounts of fishery products in feed have been implicated in outbreaks of illness, e.g., diarrhoea, and poor growth performance among animals. High levels of histamine or other biogenic amines have been proposed as causative agents (Skadborg 1985, Eggum et al. 1988b, Klausen 1988).

Biogenic amines or their products are considered of interest in relation to the quality of foodstuffs of animal origin and fur-animal feed. Information on types, combinations and concentrations of the actually harmful compounds causing the problems observed in fermented offal of animal origin (Lassén et al. 1990, Urlings 1992) is scanty. Some of the problems associated with poor quality mink feed and the role of protein decomposition products in feed deterioration have been studied by Eggum et al. (1987). The results indicate that several problems still need to be solved, and that reproducible, simple and efficient methods for feed quality control have to be developed and evaluated. This study focused on improving the analytical control of fermented silage to be used as animal feed by High Performance Liquid Chromatography (HPLC) determination of free amino acids and biogenic amines, and the relationship between them.

\section{Material and methods}

Biogenic amines and free amino acids were analysed at the Chemistry Department, Royal Veterinary and Agricultural University, Denmark.

To obtain fish silage of different qualities (silos 1 to 3 ), herring offal was fermented with $10^{7}$ colony forming units (cfu) Lactobacillus plantarum $(L . p /)$ g and 0,2 , and $5 \%(\mathrm{w} / \mathrm{w})$ dextrose at $25^{\circ} \mathrm{C}$ (Lassén 1993a). The effects of different starter cultures on the biological quality of different raw materials were studied by fermenting herring offal (silos 4 to 7 ) and poultry waste (silos 8-11) with four different starter cultures (L.p, L.p:Pediococcus pentosaceus (P.p), L.p:Pediococcus acidilactici (P.a), and Pelzyme $\left.{ }^{\circledast}\right)$, and $5 \%(\mathrm{w} / \mathrm{w})$ dextrose at $25^{\circ} \mathrm{C}$ (Lassén 1993b). Analyses for amino acids and biogenic amines were made after $0,1,2$, and 7 days' storage (silos 1-3), and in samples taken weekly during the 4 weeks' storage period (silos 4-11). Samples were frozen immediately, freeze dried, minced and homogenized. They were analysed for free amino acids and biogenic amines using modifications of methods described by Bjerg et al. (1984). Samples composed of $200 \mathrm{mg}$ of fermented material and $200 \mu \mathrm{l}$ of internal standard solution ( $2 \mu \mathrm{mol}$ 3,4-Dimetoxy Phenylmetylamin and $3 \mu \mathrm{mol}$ Norvaline/g) were extracted three times in $5 \mathrm{ml}$ of $70 \%$ boiling methanol. The raw extract was air dried overnight, dissolved in $2 \mathrm{ml}$ of water and separated into basic amino acids and biogenic amines using CM-Sephadex $25^{\circledR}$ (Pharmacia, Sweden) ion exchange column (A) and into neutral and acidic amino acids using Dowex 50w x 8200 mesh $^{\star}$ (Pharmacia, Sweden) ion exchange column (B). The A column was eluated with $4 \mathrm{M}$ acetic acid:methanol solution (1:1) and the B column with $2 \mathrm{M}$ Pyridine solution. Both eluates were air dried overnight and dissolved in $500 \mu \mathrm{l}$ of water and purified over $1 \mathrm{~mm}$ Bondapac $\mathrm{C} 18^{\circ}$ (Pharmacia, Sweden). The Bondapac column was eluated with $1.5 \mathrm{ml}$ of water and the eluates were air dried overnight and resolved in $200 \mu \mathrm{l}$ of water. $10 \mu \mathrm{l}$ of solution was used for quantitative determination by HPLC. The HPLC method used was pre-column derivation with OPA ( 25 $\mathrm{mg} \sigma$-Phatalaldehyde OPA, $2 \mathrm{ml}$ methanole, 250 $\mu \mathrm{l}$ potassium borate, and $25 \mu \mathrm{l}$ mercapto propionicacid) (B-eluates) and NAP (16.5 mg $\mu$ Phatalaldehyde, $1.32 \mathrm{ml}$ methanole, $165 \mu \mathrm{l}$ potassium borate, and $29.73 \mathrm{mg} \mathrm{N}$-acetyl-D-penicillum, NAP) (A-eluates). A-eluates were eluated for 60 minutes with $25 \mathrm{mM}$ phosphatebuffer (A) and $90 \%$ acetonitrile (C) using the following gradient: 0 min $90 \%$ (A): $10 \%$ (B); 45 65:35; 50 40:60; 60 90:10; B-eluates were eluated for 
Vol. 4: 27-33.

60 minutes with $25 \mathrm{mM}$ phosphatebuffer (A) and $50 \%$ acetonitrile:phosphatebuffer $(B)$ with the following gradient: 0 min 100\% (A):0\% (B); 20 80:20; 40 65:35; 50 40:60; 60 100:0. The HPLC column was a SuperPac spherisorb ODS $2^{\circledast} 3 \mu \mathrm{m}$ x $125 \mathrm{~mm}$ (Pharmacia, Sweden) and the column temperature was $30^{\circ} \mathrm{C}$, flow rate was $1 \mathrm{ml} / \mathrm{min}$, and the absorbance was measured at $340 \mathrm{~nm}$. The raw data were processed by computer with an HPLC manager (Pharmacia, Sweden).

Feed quality was presented by a quality index (QI) expressed by the following formula;

$\mathrm{QI}=$

$$
\text { (Lysine + Arginine + Tyrosine })
$$

(Ornithine + Cadaverine + Putrescine + Tyramine)

Samples from the 11 different treatments described above were analysed for contents of free amino acids and biogenic amines, and the quality of the silage was evaluated according to QI. To estimate the degree of proteolysis, the alanine content was recorded in addition to QI.

\section{Results}

The study showed that herring offal (silo 1) could be stored anaerobically for two days at $25^{\circ} \mathrm{C}$

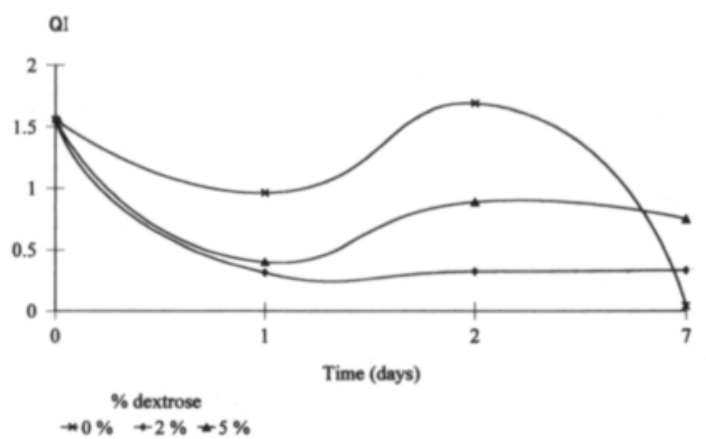

Fig. 1. Quality index (QI) for herring offal (silos 1-3) fermented with $10^{7}$ colony forming units/g Lactobacillus plantarum and 0,2 , and $5 \%$ dextrose at $25^{\circ} \mathrm{C}$.

without affecting quality as measured by QI; however, it putrefied after one week of storage. Offal in silo 2 also putrefied after one week of storage, but fermentation with 5\% dextrose (silo 3) resulted in stable silage with a high QI $(0.75)$ after one week of storage (Fig. 1). The alanine content increased from an initial concentration of $18.7 \mu \mathrm{mol} / \mathrm{g}$ to $212.2 \mu \mathrm{mol} / \mathrm{g}$ after one week in silo 2 , and from $16.5 \mu \mathrm{mol} / \mathrm{g}$ to $148.4 \mu \mathrm{mol} / \mathrm{g}$ in silo 3 . If no dextrose was added (silo 1), alanine decreased from an initial concentration of $24 \mu \mathrm{mol} / \mathrm{g}$ to $7.9 \mu \mathrm{mol} / \mathrm{g}$ after two days and then increased once more to $14.0 \mu \mathrm{mol} / \mathrm{g}$ after one week (Table 1).

In herring offal (silos 4-7) QI increased during the first week of storage and then decreased

Table 1. Changes in alanine content $(\mu \mathrm{mol} / \mathrm{g})$ during storage for silage of different organoleptic qualities (silos 1-3) and for herring offal (silos 4-7) and poultry waste (silos 8-11) fermented with different starter cultures.

\begin{tabular}{|c|c|c|c|c|c|c|c|c|c|c|}
\hline \multicolumn{6}{|c|}{ Storage time Days } & \multicolumn{5}{|c|}{ Storage time Weeks } \\
\hline $\mathrm{S}^{*}$ & 0 & 1 & 2 & 7 & $\mathrm{~S}^{*}$ & 0 & 1 & 2 & 3 & 4 \\
\hline 1 & 24.0 & 13.7 & 7.9 & 14.0 & 4 & 14.5 & 142.2 & 145.0 & 218.8 & 214.3 \\
\hline 2 & 18.7 & 43.3 & 58.6 & 212.2 & 5 & 7.8 & 56.5 & 89.2 & 103.3 & 120.5 \\
\hline \multirow[t]{6}{*}{3} & 16.5 & 26.6 & 50.6 & 148.5 & 6 & 11.3 & 55.6 & 97.1 & 123.3 & 149.6 \\
\hline & & & & & 7 & 25.0 & 59.8 & 80.8 & 184.1 & 104.1 \\
\hline & & & & & 8 & 20.1 & 97.4 & 120.1 & 144.7 & 183.8 \\
\hline & & & & & 9 & 44.0 & 98.9 & 112.5 & 134.6 & 144.0 \\
\hline & & & & & 10 & 34.4 & 85.94 & 113.0 & 135.7 & 156.4 \\
\hline & & & & & 11 & 35.0 & 98.2 & 104.3 & 139.2 & 203.1 \\
\hline
\end{tabular}

* $\mathrm{S}=$ silo number 
Lassén, T. M.: Biological quality of fermented fish offal and chicken by-products

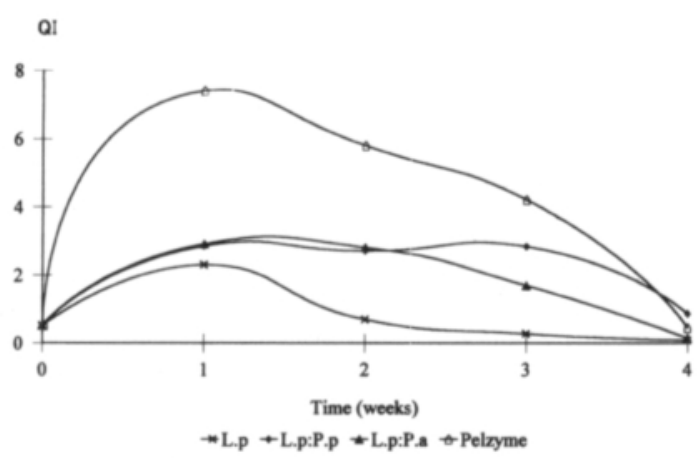

Fig. 2. Quality index (QI) for herring offal (silos 4-7) fermented with different lactic acid bacteria cultures $\left(10^{8}\right.$ colony forming units $/ \mathrm{g}, 5 \%$ dextrose at $25^{\circ} \mathrm{C}$ ).

and stabilized at about 0.75 for good quality silage and 0.25 for poor quality silage (Figure 2.). In this type of raw material alanine increased during the first three weeks from an initial concentration of $14.5 \mu \mathrm{mol} / \mathrm{g}$ to $218.8 \mu \mathrm{mol} / \mathrm{g}$ (L.p), and from $25.0 \mu \mathrm{mol} / \mathrm{g}$ to $184.1 \mu \mathrm{mol} / \mathrm{g}$ $\left(\right.$ Pelzyme $^{\circledast}$ ), and then decreased to $214.3 \mu \mathrm{mol} /$ $\mathrm{g}$, and $104.1 \mu \mathrm{mol} / \mathrm{g}$, respectively. For L.p:P.p and L.p:P.a alanine increased throughout the period from initial concentrations of $7.8 \mu \mathrm{mol} / \mathrm{g}$ and $11.3 \mu \mathrm{mol} / \mathrm{g}$ to $120.5 \mu \mathrm{mol} / \mathrm{g}$ and 149.6 $\mu \mathrm{mol} / \mathrm{g}$, respectively (Table 1 ), but increasing concentrations of biogenic amines, especially tyramine, resulted in a low QI. The quality of the fermented silage was acceptable for all four types of silage, Pelzyme ${ }^{\circledast}$ yielding the most acceptable odour and texture.

There was no major difference in QI between poultry wastes (silo $8-11$ ), except slightly increased QI for silage fermented with L.p:P.p and L.p:P.a after two weeks of storage, but after four weeks of storage the final QI was almost the same (Figure 3). Alanine content (Table 1) increased throughout the period of storage from an initial concentration of $20.1 \mu \mathrm{mol} / \mathrm{g}$ to 183.8 $\mu \mathrm{mol} / \mathrm{g}$ (L.p), $44.0 \mu \mathrm{mol} / \mathrm{g}$ to $134.6 \mu \mathrm{mol} / \mathrm{g}$ (L.p:P.p), $34.4 \mu \mathrm{mol} / \mathrm{g}$ to $156.4 \mu \mathrm{mol} / \mathrm{g}$ (L.p:P.a), and $35 \mu \mathrm{mol} / \mathrm{g}$ to $203.1 \mu \mathrm{mol} / \mathrm{g}$ (Pelzyme ${ }^{\star}$ ). The quality of the fermented silage was acceptable for all silages with a primarily sour odour after four weeks of storage. The offal liquefied after

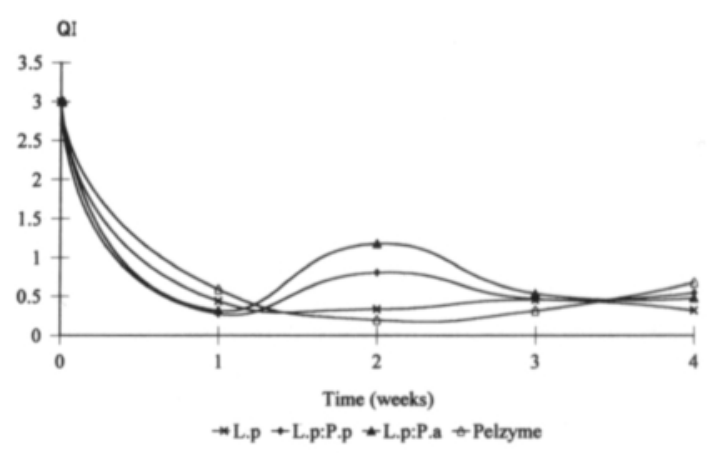

Fig. 3. Quality index (QI) for chicken offal (silos 8-11) fermented with different lactic acid bacteria cultures $\left(10^{8} \mathrm{col}-\right.$ ony forming units $/ \mathrm{g}, 5 \%$ dextrose and $12 \%$ extruded wheatmeal:feathers $(2: 1)$ at $\left.25^{\circ} \mathrm{C}\right)$.

one week of fermentation, and separated into oily, aqueous and solid fractions due to hydrolysis of the material; herring offal was the most liquefied.

\section{Discussion}

QI is a new way of presenting analytical information obtained from analyses of the amino acids released from protein and accumulated biogenic amines. The amino acids lysine, arginine, and tyrosine were used in the index for the estimation of quality, because they are readily released from protein and metabolised to the corresponding biogenic amines (cadaverine, ornithine and putrescine, and tyramine). Histidine and histamine were not chosen, because increased concentrations of histamine in fermented products (herring offal and chicken offal) were only detected when the product was already organoleptically unacceptable. The alanine content was chosen as a tool to compare the amounts of amino acids released from protein over time, because alanine is readily released but hardly metabolised at all during storage. Therefore, the reliability of QI improves with simultaneous recording of alanine content in the product.

The finding of a low QI in spoiled fish offal 


\section{AGRICULTURAL SCIENCE IN FINLAND}

Vol. 4: 27-33.

(stored at $25^{\circ} \mathrm{C}$ for one week, silo 1) was as expected, due to the high concentrations of biogenic amines. Spoiled herring offal was, however, characterized by an increase in QI during the first two days of storage, primarily due to low concentrations of biogenic amines. This is probably an outcome of less hydrolase activity and slower release of amino acids from protein in unfermented herring offal, which was confirmed by lower concentrations of free alanine. After one week at $25^{\circ} \mathrm{C}$ almost all the released amino acids had decomposed to biogenic amines (cadaverine and tyramine) and ornithine, whereas the more stable silage (silo 3) had a higher QI due to lower concentrations of biogenic amines. High concentrations of biogenic amines were also found in poor quality silage (silo 2) after one week of storage (low QI). When herring offal was fermented with different lactic acid bacteria (LAB) (silos 4-7), a difference in QI development between the cultures was observed, the silage culture Pelzyme ${ }^{\oplus}$ generally having a higher QI than the others. For chicken offal fermented under similar conditions (silos 8-11) no major difference between the LAB cultures tested was observed. Fermented silage was generally characterized by an increased alanine concentration over time, which describes the hydrolysation and proteolytic activity in the silage.

Using QI not only provides a simple way of expressing feed quality, but also a way of comparing analyses based on wet weight (ww) and dry matter. Data from a study by Klausen (1988), recalculated to QI, give the following information. At the beginning of the storage, herring viscera had a very high QI $\left(10^{\circ} \mathrm{C}: 10.2\right.$ and $20^{\circ} \mathrm{C}: 6.9$ ), due to the high content of free amino acids and low concentrations of biogenic amines. After $24 \mathrm{~h}$ QI decreased to 1.15 and 0.98 , respectively, and finally decreased to 0.29 and 0.20 , at which point the herring viscera were considered putrefied and spoiled.

Both in the present study and in that of Klausen (1988), low QI could be explained by a high content of biogenic amines (tyramine and cadaverine) and low concentrations of free amino acids in the herring viscera. An initial increase in QI can be attributetd to release of amino acids from protein with little or no transformation into biogenic amines. This was often observed during the first week of storage after successful initial fermentation (silos 4, 6, and 7). However, after one week of storage, QI decreased, and high concentrations of biogenic amines and ornithine were observed after four weeks of storage, even if the $\mathrm{pH}$ and redox potential in the silage were still low enough (Lassén 1993b) to inhibit enzyme activity. The lactic acid producing bacteria itself might be responsible for ADC activity at low $\mathrm{pH}$, because most of the spoilage bacteria are inhibited at $\mathrm{pH}<4.5$ or lack cellular activity (Lindgren 1985). The biochemistry of fish viscera is obviously quite different from that of the fillet (Børresen et al. 1988), but studies on the biochemistry of fish viscera are scanty. Stede and Stockemer (1981) found for whole herring stored at $6^{\circ} \mathrm{C}$ that the viscera contained $1.00 \mu \mathrm{mol}$ histamine/g ww after 2 days at $6^{\circ} \mathrm{C}$. Corresponding values for herring fillet were $0.41 \mu \mathrm{mol}$ histamine/g ww. Klausen (1988) studied the content of free amino acids and biogenic amines in herring fillet and herring viscera stored at $0^{\circ} \mathrm{C}$ for 10 days, and found the contents of tyramine, cadaverine and agmatine in the viscera to be approximately 1000,200 and 125 times, respectively, the contents found in the fillet. Børresen et al. (1988) found the concentration of most biogenic amines in freshly caught herring to be lower than $15 \mathrm{nmol} / \mathrm{g}$ ww in the fillet, and 1.5 $\mu \mathrm{mol} / \mathrm{g}$ ww in the viscera, which was supported by the results obtained here.

The biochemistry of fermented poultry offal is largely unknown, but Urlings (1992) studied the concentrations of biogenic amines in poultry offal fermented with $10 \%$ beet pulp, $2 \%$ dextrose and Lactobacillus plantarum and stored at $15^{\circ} \mathrm{C}$ for 21 days, and found lower concentrations than those reported by Eggum et al. (1987, 1988b).

Eggum et al. (1987) found very low concentrations of biogenic amines in offal from freshly slaughted poultry, but cadaverine and tyramine increased heavily after $24 \mathrm{~h}$ at $20^{\circ} \mathrm{C}$. This finding was supported by the present study, in which 
Lassén, T. M.: Biological quality of fermented fish offal and chicken by-products

cadaverine and tyramine increased during the first week of fermentation from almost undetectable concentrations, $(0.6$, and $0.3 \mu \mathrm{mol} / \mathrm{g} \mathrm{DM}$, respectively) to $12.7 \mu \mathrm{mol} / \mathrm{g} \mathrm{DM}$, and $13.3 \mu \mathrm{mol} /$ g DM, respectively.

There are various possible mechanisms for explaining the accumulation of free amino acids and biogenic amines in fermented silage (Eggum et al. 1988a, Klausen 1988). Undoubtedly the pattern observed in the present study resulted from the combined effect of autolytic and microbial enzyme activities in which amino acids were released from protein. Biogenic amines were formed from free amino acids by autolytic decarboxylation or decarboxylation by microbial enzymes and removed by oxidative deamination or other unidentified pathways. The decreased alanine concentration in putrefied silage might be explained by the Stickland reaction, in which alanines react with glycine and $\mathrm{H}_{2} \mathrm{O}$ to form acetic acid, ammonia and carbon dioxide (Schlegel 1986).

From the present and earlier studies (Lassén et al. 1990, Urlings 1992), it can be concluded that accumulation of biogenic amines in fermented animal by-products is a problem due to the decarboxylase activity caused by the LAB cultures added. QI might be an informative way of presenting and comparing data on biological feed quality in fermented animal by-products, and its informative value increases if combined with concentration of free alanine and parameters such as lactic acid production, $\mathrm{pH}$ and changes in redoxpotential. Changes in concentrations of both biogenic amines and free amino acids during storage ought, however, to be presented in $\mu \mathrm{mol}$ active molecules/g material regardless of whether the analyses are performed on dry or wet material.

Acknowledgements. Financial support for this study was provided by the Academy of Finland. Sincere gratitude is due to Mrs Birthe Jessen of Chr. Hansen's Lab, A/S, Hørsholm, Denmark for providing the starter cultures, to $\mathrm{Mr}$ Peter Møller of the Chemistry Department, for helpful and skilful assistance with HPLC analyses, and to Associate Professors Niels Enggaard Hansen, Anne-Helene Tauson and Hilmer Sørensen for valuable suggestions and comments regarding the manuscript.

\section{References}

Bjerg, B., Olsen, O., Rasmussen, K. W. \& Sorensen, H. 1984. New principles of ion exchange techniques suitable to sample preparation and group separation of natural products prior to liquid chromatography. Journal of Liquid Chromatography 7: 691-707.

Borresen, T., Klausen, N. K, Larsen, L. M. \& Sørensen, H. 1988. Aminosyredekarboxylaser; Egenskaber og relation til biogene aminer og kvalitet af pelsdyrfoder. Faglig Årsberetning 1987. Dansk Pelsdyravlerforening. p. 174184.

Eggum, B. O., Hansen, N. E., Henriksen, P. \& Sorensen, H. 1987. Biogene aminer i pelsdyrfoder. Faglig Årsberetning 1986. Dansk Pelsdyravlerforening. p. 233245.

-, Hansen, N. E., Henriksen, P. \& Sorensen, H. 1988b. Biogene aminer i relation til kvalitet af pelsdyrfoder. Faglig Årsberetning 1987. Dansk Pelsdyravlerforening. p. 185207.

-, Hansen, N. E. \& Sorensen, H. 1988a. Amino acid precursors of biogenic amines. In: Friedman, M. (ed.). Absorption and utilization of amino acids. CRC Press, Boca Raton, Florida. 42 p.

Klausen, N. K. 1988. Decarboxylation of tyrosine in re- lation to metabolism of amino acids and biogenic amines in fish during storage: Enzymes, Kinetics, and importance. Ph.D Thesis, Chemistry Department, Royal Veterinary and Agricultural University, Denmark. $185 \mathrm{p}$.

Lassén, T. M. 1995a. Evaluation of conditions for fermentation of fish offal. Agricultural Science in Finland 4: 11-17.

- 1995b. Lactic acid fermentation of fish offal and chicken by-product with different starter cultures. Agricultural Science in Finland 4: 19-26.

-, Hildén, A., Hildén, B. H. \& Laitinen, M. J. 1990. Praktisk tillämpning av erfarenheter från försök med biologisk konserverad ensilage i foder till mink och răv. NJFUtredning/Rapport Nr. 60. 20 p.

Lindgren, S. E. 1985. Användning av mjölksyrajäsande bakterier för konservering av animaliska rávaror. NJFSeminarium Nr. 85. Aalborg, Denmark. 6 p.

Schlegel, H. G. 1986. General Microbiology. Sixth Edition Cambridge University Press. Cambridge, UK. p. 293302.

Skadborg, J. 1985. Sundhedsskadelige stoffer dannet ved mikrobiologisk, enzymatisk og oxidativ aktivitet i foder till pelsdyr. Hovedopgave i Pelsdyrproduktion, Royal Vet- 
Vol. 4: 27-33.

erinary and Agricultural University, Denmark. 64 p.

Stede, M. \& Stockemer, J. 1981. Bildung von Histamin in frischen Heringen und Makrelen. Fleischwirtschaft 61: 1746-1749.

Taylor, S. L. 1986. Histamine Food Poisoning: Toxicology and Clinical Aspects. CRC Critical Reviews in Toxicology 17: 91-128.
- 1988. Marine toxins of microbial origin. Food Technology 42: 94-98.

Urlings, H. A. P. 1992. Fermentation of animal by-products. Microbiological aspects of processing, epidemiology and animal nutrition. Diss. Utrecht University, Faculty of Veterinary Medicine, Department of the Science of Food of Animal Origin, Utrecht, The Netherlands. 135 p.

\title{
SELOSTUS
}

\section{Fermentoitujen kala- ja kanajätteiden biologinen laatu}

\author{
T. Mikael Lassén \\ Royal Veterinary and Agricultural University, Tanska
}

Tutkimuksessa selvitettiin fermentoitujen kala- ja kanajätteiden biologista laatua. Tutkituille jätteille määritettiin laatuindeksi, jonka määrittämiseksi analysoitiin tärkeät vapaat aminohapot ja niitä vastaavat biogeeniset aminit. Näytteet analysoitiin ryhmäerottelu-menetelmällä, joka perustuu ioninvaihtokromatografiaan. Biologinen laatu tutkittiin näytteistä, jotka olivat eri bakteeriviljelmistä, erikokoisista siirrostuksista ja erilaisilta kasvualustoilta.

Hidas tai epätäydellinen fermentaatio aiheutti biogeenisten aminien, erityisesti tyramiinin, määrän kasvun ja lopputuloksena oli alhainen laatuindeksi. Nopean alkufermentaation ja jatkuvan vakaan neljän viikon fermentaation seurauksena oli alhainen biogeenisten aminien pitoisuus, korkea vapaiden aminohappojen pitoisuus ja korkea laatuindeksi.

Alaniinipitoisuuden todettiin olevan käytännöllinen proteolyysin arviointiväline. Lisäksi muutokset alaniinipitoisuudessa vaikuttivat laatuindeksiin. Maitohappopitoisuus ja redox-potentiaali soveltuivat kaikkein parhaiten fermentoitujen kala- ja kanajätteiden biologisen laadun arviointiin. 